\title{
Occurrence of Extended Spectrum Beta Lactamase Producing Escherichia coli in Hyena from Chhattisgarh, India
}

\author{
Chandrahas Sannat $^{1^{*}}$, Anil Patyal ${ }^{2}$, Nidhi Rawat ${ }^{1}$, Jasmeet Singh ${ }^{3}$, \\ Choodamani Chandrakar $^{2}$, Sanjay Shakya ${ }^{2}$ and S. D. Hirpurkar ${ }^{1}$
}

${ }^{1}$ Department of Veterinary Microbiology, ${ }^{2}$ Department of Veterinary Public Health and Epidemiology, College of Veterinary Science \& A.H., Anjora, ${ }^{3}$ Wildlife Health and Forensic center, Chhattisgarh Kamdhenu Vishwavidyalaya, Durg, Chhattisgarh, INDIA

*Corresponding author

\section{A B S T R A C T}

\begin{tabular}{l} 
K e y w o r d s \\
Hyena, Multi drug \\
resistant \\
Escherichia coli, \\
ESBL, Chhattisgarh \\
\hline Article Info \\
$\begin{array}{l}\text { Accepted: } \\
\text { 15 December } 2019 \\
\text { Available Online: } \\
\text { 20 January } 2020\end{array}$ \\
\hline
\end{tabular}

Present study was aimed to characterize Escherichia coli isolated from wound from a hyena. Pus swab collected from wound was processed for bacterial isolation and identification as per standard protocol. Isolate was then subjected to antimicrobial susceptibility test by disc diffusion method using commercial available antibiotics such as ampicillin, amoxycillin, amoxyclav, trimethoprim, chloramphenicol, ciprofloxacin, enrofloxacin, cefepime, cefotaxime, ceftriaxone, ceftriaxone/tazobactum, gentamicin and oxytetracycline. Further isolate was screened for presence of extended spectrum beta lactamase genes (blaSHV, blaTEM and blaCTX-M) by PCR. Bacterial culture, staining and biochemical properties revealed the presence of Escherichia coli. Escherichia coli was found susceptible to chloramphenicol and intermediate sensitive to ceftriaxone/ tazobactum and gentamicin and resistant to ampicillin, amoxycillin, amoxyclav, trimethoprim, ciprofloxacin, enrofloxacin, cefotaxime, cefepime, ceftriaxone and oxytetracycline. Escherichia coli isolate was found positive for blaCTX-M genes whereas blaSHV and blaTEM genes were not detected. In conclusion, investigation of present study revealed the presence of multi drug resistant and extended spectrum beta lactamase producing Escherichia coli in hyena.

\section{Introduction}

Antimicrobial resistance is not only threat to human and livestock health but also have huge wildlife concern because close interaction between wildlife, livestock and human can lead to interspecies transmission of pathogenic bacteria including strains that exhibit antimicrobial resistance (Lloyd, 2007). One of the most common antimicrobial resistance mechanisms in Enterobacteriaceae is production of extended spectrum beta lactamases (ESBL) enzymes. During last few decades, evolution and dissemination of betalactam resistance in Escherichia coli (E. coli) and other gram negative bacteria became a 
challenge worldwide. Beta-lactam resistance in $E$. coli can be acquired through generation of ESBL; acquisition of genes encoding ESBL (CTX-M) or due to high level expression of chromosome encoded beta lactamases (bla) genes (Pfeifer et al., 2010). During 1980s and 1990s, the majority of the ESBLs were the SHV or TEM types (Peterson and Bonomo, 2005) but later ESBL pandemics occurs in E. coli due to widespread occurrence of CTX-M beta lactamases (Pitout, 2012).

The study of wildlife as guard of antimicrobial resistance has recently acquired more consideration globally (Huijbers et al., 2015) and E. coli has been described as principal indicator of the selective pressure in wildlife (van den Bogaard and Stobberingh, 2000). However, there is inadequate information pertaining to existence of antimicrobial resistance in wildlife in India and; Chhattisgarh in particular. Therefore, present study was made to investigate the existence of multidrug resistant (MDR) $E$. coli in hyena from Chhattisgarh, India.

\section{Materials and Methods}

\section{Sample processing}

Pus swab collected from wound in a hyena was brought in the laboratory of Veterinary Microbiology, Veterinary College Anjora from Directorate of wildlife and forensic science, Chhattisgarh Kamdhenu Vishwavidyalaya, Durg, Chhattisgarh (India).

Swab was initially enriched in sterile normal saline for 2 hours. Enriched swab was then inoculated into brain heart infusion broth and incubated for 24 hours at $37^{\circ} \mathrm{C}$. Broth culture was examined for morphology of organism by Gram's staining and then subjected to isolation of specific bacteria.

\section{Isolation and identification of bacteria}

Standard methodology was used for isolation and identification of bacteria (Holt et al., 1994). Broth culture depicting Gram negative bacilli was streaked on to Mac Conkey Lactose (MLA) agar and incubated at $37^{\circ} \mathrm{C}$ for $24 \mathrm{hrs}$. Pink colonies on MLA was picked up and was then inoculated on eosine methylene blue (EMB) and 10\% sheep blood agar and incubated at $37^{\circ} \mathrm{C}$ for $24 \mathrm{hrs}$. Bacterial isolate was identified through a series of biochemical tests viz. Catalase, oxidase, motility, indole production, methyl red, Voges Proskauer, citrate utilization, urease and $\mathrm{H}_{2} \mathrm{~S}$ production in triple sugar iron agar (TSI) slant.

\section{Antimicrobial susceptibility test}

The antimicrobial susceptibility test was done in Muller Hinton agar using disc diffusion method as described by Bauer et al., (1966). Antibiotic discs of commercially available antimicrobials such as ampicillin $(10 \mu \mathrm{g})$, amoxycillin (30 $\mathrm{g})$, amoxyclav $(30 \mu \mathrm{g})$, trimethoprim $(10 \mu \mathrm{g})$, chloramphenicol $(30 \mu \mathrm{g})$, ciprofloxacin $(5 \mu \mathrm{g})$, enrofloxacin $(10 \mu \mathrm{g})$, cefepime $(30 \mu \mathrm{g})$, ceftriaxone $(30 \mu \mathrm{g})$, ceftriaxone/tazobactum $\quad(30 / 10 \quad \mu \mathrm{g})$, gentamicin $(10 \mu \mathrm{g})$, oxytetracycline $(30 \mu \mathrm{g})$ and cefotaxime $(10 \mu \mathrm{g})$ procured from Himedia laboratories were used. The diameter of zone of inhibition (in $\mathrm{mm}$ ) was measured and categorized as susceptible, intermediate or resistant.

\section{Extraction of genomic DNA}

Extraction of bacterial genomic DNA was performed by snap chill method (Nagappa et al., 2007). Briefly, a single colony was inoculated into nutrient broth and incubated at $37^{\circ} \mathrm{C}$ overnight. Then, $1.5 \mathrm{ml}$ of the bacterial culture was centrifuged at $8000 \mathrm{rpm}$ followed by three times washing of pellet in PBS. 
Pellet was then eluted in $100 \mu 1$ nuclease free water and kept in to boiling water bath for 10 minutes which is followed by quick chilling in ice. Cconcentration and purity of extracted DNA was determined by $0.8 \%$ agarose gel electrophoresis and then stored at $-20^{\circ} \mathrm{C}$ till further use.

\section{Polymerase Chain Reaction (PCR) for detection of ESBL gene}

Detection of the ESBL gene sequence coding for the TEM, SHV, CTX-M enzymes (Table 1) were performed by the multiplex PCR as described by Akpaka et al., (2010) with slight modifications. Amplified PCR products were electrophoresed on $1.5 \%$ agarose gel stained with ethidium bromide $(0.5 \mu \mathrm{g} / \mathrm{ml})$. The images of ethidium bromide stained DNA bands were analysed under UV transilluminator (Biometra) and digitized using a Gel Documentation System (Gel Doc $^{\mathrm{TM}} \mathrm{XR}$, Biorad, USA). Molecular reagents used during present study were procured from Thermo Scientific (USA) and Bangalore Genei (India).

\section{Results and Discussion}

The bacterial isolate obtained from wound from hyena during present investigation was morphologically gram negative, rods in shape, non-spore forming with peritrichous flagella. Isolate was lactose fermenter which produced pink colonies on MLA and greenish metallic sheen on EMB agar. On Blood agar, colonies were non haemolytic. Yellow slant and yellow but without $\mathrm{H}_{2} \mathrm{~S}$ production was observed in TSI slant. Isolates showed positive reaction for catalase, indole and methyl red, but negative test for oxidase, urease, citrate and Voges-Proskauer. Cultural, staining and biochemical characteristics of bacterial isolate during present study was in accordance and confirmation with the $E$. coli as reported by earlier workers (Forbes et al., 2007; Mohammed and AL-Khyat, 2008).
Present study reported MDR E. coli from hyena. Antimicrobial susceptibility test of $E$. coli revealed that organism was highly sensitive to chloramphenicol; intermediate sensitive to ceftriaxone/tazobactum and gentamicin and resistant to ampicillin, amoxycillin, amoxyclav, trimethoprim, ciprofloxacin, enrofloxacin, cefotaxime, cefepime, ceftriaxone and oxytetracycline. In a similar type of study, Jobbins and Alexander (2015) and Pesapane et el. (2013) reported MDR E.coli in faeces of hyena and they also observed that multidrug resistance was significantly higher in carnivores suggesting the life history and food chain may be the key to understanding the exposure patterns and transmission dynamics. Wasyl et al., (2018) reported MDR E. coli from wild boar exhibiting resistance against 11 of 14 tested antimicrobials including sulfamethoxazole, ampicillin, trimethoprim and tetracycline. In accordance with the present finding, earlier workers have reported resistance of $E$. coli towards aminoglycosides, fluoroquinolones and ceftriaxone (Sharma et al., 2016) in human and towards ampicillin, enrofloxacin, trimethoprim and amoxcyclav in canine (Wong et al., 2015). Increased sensitivity of E.coli towards chloramphenicol during present study corroborates with observation of Kibret and Abera (2011). Similarly, Sood (2016) reported $83 \%$ of the MDR E. coli isolate sensitive to chloramphenicol. Re-emergence of chloramphenicol sensitivity might be due to decreased frequency of its use in recent years, thereby not giving the bacteria much possibility to develop resistance.

During present investigation, E. coli isolate from hyena was found to harbour blaCTX-M gene (Fig.1) whereas other two ESBL genes (blaSHV and blaTEM) were not detected by PCR amplification. Present report was in agreement with the findings of Darwich et al., (2019) who reported higher prevalence of 
beta lactamase genes (bla SHV 20\%, blaCTX-M, 18\%) in wild animals. Likewise, Wasyl et al., (2018) detected ESBL genes (blaCTX-M) producing E. coli in wild boar. On contrary, Alonso et al., (2017) described lower prevalence of betalactamase producing E. coli in wild mammals as compared to wild birds.

Emergence of MDR E.coli in hyena need to be understand. It is well documented that use of antibiotics is the most direct mechanism for the evolution of antimicrobial resistant pathogens in livestock and man. Horizontal transfer via transposon and plasmids facilitate resistant genes to spread rapidly through bacterial populations (Peterson and Kaur, 2018). 30-90\% of the antibiotics administered in animals and man are excreted unmetabolized which causes environmental diffusion of resistant bacteria and present a direct source for onward transmission to wild animals (Marshall and Levy, 2011). As wildlife is not directly exposed to any antimicrobial agent, therefore fecal contamination of water or soil with MDR bacteria can lead to selection pressure. Besides socioeconomic factors such as forest fragmentation (Goldberg et al., 2008), research and tourism (Goldberg et al., 2007), urbanization and intensification of agriculture and livestock (Jones et al., 2008) may lead to close interaction of wild animals with livestock and human, thereby leading to emergence of antimicrobial resistance in wildlife. In ordinary circumstances, hyenas are extremely timid around humans and sometimes implicated in the killing of livestock (Heptner and Sludskii, 1992), which makes close interface between livestockhuman and hyena facilitating the rapid interspecies dissemination of resistant pathogens. It is well supported with the observations of Dorado-Garcia et al., (2018) and Weiss et al., (2018) who reported similar ESBL genes in human and wild life settings; and identical MDR pattern of $E$. coli in livestock, wildlife and human, respectively. Similarly, Rwego et al., (2008) also demonstrated high rate of $E$. coli transmission between livestock and humans.

Table.1 Details of ESBL gene primers

\begin{tabular}{|c|c|c|c|}
\hline Gene & Primer sequence & Length & References \\
\hline blaSHV & $\begin{array}{l}\text { 5'- ATG CGT TAT ATT CGC CTG TG - 3' } \\
\text { 5'- TGC TTT GTT ATT CGG GCC AA - 3', }\end{array}$ & 747-bp & $\begin{array}{l}\text { (Paterson et al., } \\
\text { 2003) }\end{array}$ \\
\hline blaTEM & $\begin{array}{l}\text { 5' - TCG CCG CAT ACA CTA TTC TCA GAA TGA - 3' } \\
\text { 5' - ACG CTC ACC GGC TCC AGA TTT AT - 3', }\end{array}$ & 445-bp & $\begin{array}{l}\text { (Akpaka et al., } \\
\text { 2010) }\end{array}$ \\
\hline blaCTX-M & $\begin{array}{l}\text { 5' - ATG TGC AGY ACC AGT AAR GTK ATG GC - 3' } \\
\text { 5' - TGG GTR AAR TAR GTS ACC AGA AYC AGC GG-3' }\end{array}$ & 593-bp & $\begin{array}{l}\text { (Boyd et al., } \\
\text { 2004) }\end{array}$ \\
\hline
\end{tabular}


Fig.1 Escherichia coli isolate positive for ESBL gene blaCTX-M. Lane 1: 100 bp ladder, Lane 3: Positive control, Lane 8: Positive for blaCTX-M genes, Lane 4, 5, 6, 7: Negative E. coli isolates

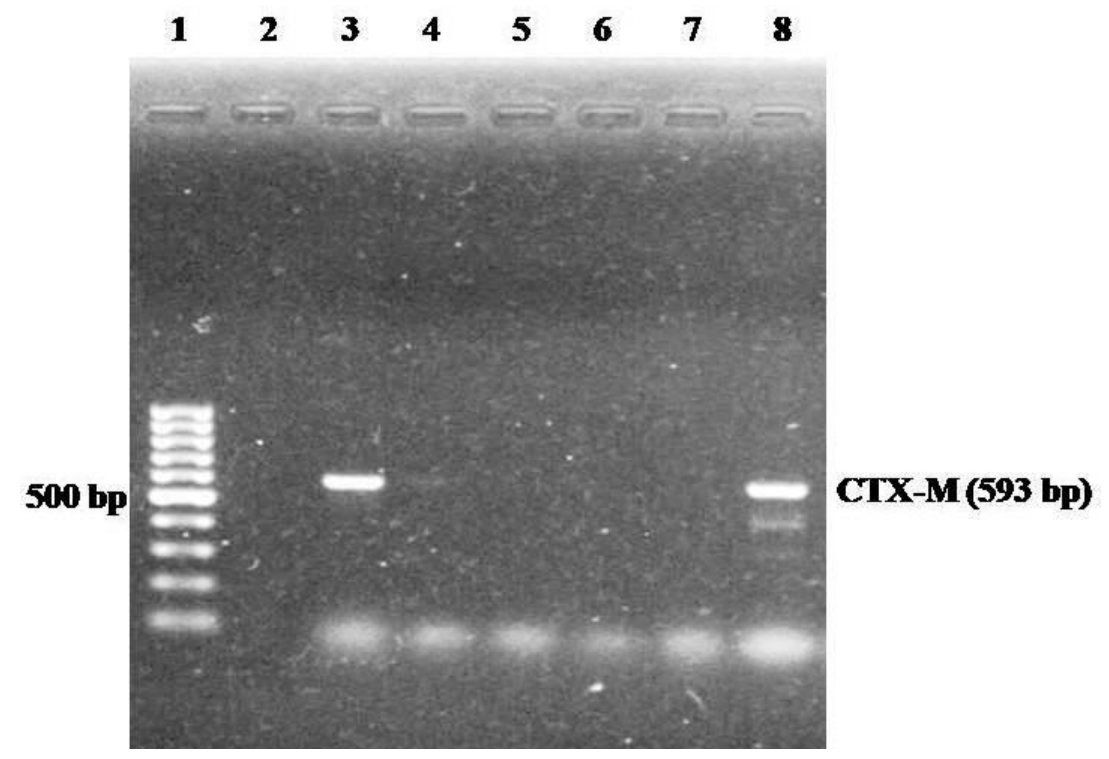

In conclusion, antimicrobial resistance has emerged as a serious problem in both veterinary and human medicine around the globe. Occurrence of MDR E. coli with extended spectrum beta lactamase activity in a hyena needs immediate attention and therefore periodic monitoring of antimicrobial susceptibility both in wildlife and surrounding human dwellings is recommended.

\section{Acknowledgments}

The authors are highly thankful to the Dean, College of Veterinary Science and Animal Husbandry, Chhattisgarh Kamdhenu Vishwa Vidyalaya, Anjora, Durg, Chhattisgarh, India for providing necessary financial assistance and instrumentation facilities to carry out this research work.

\section{References}

Akpaka, P.E., Legall, B. and Padman, J. 2010. Molecular detection and epidemiology of extended-spectrum beta-lactamase genes prevalent in clinical isolates of
Klebsiella pneumoniae and E coli from Trinidad and Tobago. West Indian Medical Journal, 59(6): 591-596.

Alonso, C. A., Zarazaga, M., Ben Sallem, R., Jouini, A., Ben Slama, K. and Torres C. 2017. Antibiotic resistance in Escherichia coli in husbandry animals: the African perspective. Letters in Applied Microbiology, 64: 318-334.

Bauer, A.W., Kirby, W.M.M., Sherris, J.C. and Turck, M. 1966. Antibiotic susceptibility testing by a standardised single disk method. American Journal of Clinical Pathology, 45(4): 493-496.

Boyd, D. A., Tyler, S., Christianson, S., McGeer, A., Muller, M. P., Willey, B. M., Bryce, E., Gardam, M., Nordmann, P. and Mulvey, M.R. 2004. Complete nucleotide sequence of a 92-kilobase plasmid harbouring the CTX-M-15 extended-spectrum $\quad \beta$-lactamase involved in an outbreak in long-termcare facilities in Toronto, Canada. Antimicrobial Agents and Chemotherapy, 48: 3758-3764.

Darwich, L., Vidal, A., Seminati, C., 
Albamonte, A., Casado, A., Lo’́pez F, Molina-Lopez, R.A. and MiguraGarcia, L. 2019. High prevalence and diversity of extended-spectrum Blactamase and emergence of OXA-48 producing Enterobacterales in wildlife in Catalonia. PLoS One, 14(8): e0210686.

Dorado-Garcia, A., Smid, J. H., Van Pelt, W., Bonten, M. J. M., Fluit, A. C., Van Den Bunt, G., Wagenaar, J.A., Hordijk, J., Dierikx, C.M., Veldman, K. T, de Koeijer, A., Dohmen, W., Schmitt, H., Liakopoulos, A., Pacholewicz, E., Lam, T.J.G.M., Velthuis, A.G., Heuvelink A, Gonggrijp, M.A., van Duijkeren, E., van Hoek, A.H.A.M., de Roda Husman, A.M., Blaak, H., Havelaar, A.H., Mevius, D.J. and Heederik, D.J.J. 2018. Molecular relatedness of ESBL/AmpCproducing Escherichia coli from humans, animals, food and the environment: a pooled analysis. Journal of Antimicrobial Chemotherapy, 73(2):339-347.

Forbes, B. A., Sahm, D. F. and Weissfeld, A. S. 2007. Bailey \& Scott's Diagnostic Microbiology 12th Edition: Mosby Elsevier, St. Louis. USA.

Goldberg, T.L., Gillespie, T.R., Rwego, I.B., Estoff, E.E. and Chapman, C.A. 2008. Forest fragmentation as cause of bacterial transmission among primates, humans, and livestock, Uganda. Emerging Infectious Diseases, 14: 1375-1382.

Goldberg, T. L., Gillespie, T. R., Rwego, I. B., Wheeler, E., Estoff, E. L. and C. A. Chapman. 2007. Patterns of gastrointestinal bacterial exchange between chimpanzees and humans involved in research and tourism in western Uganda. Biological Conservation, 135: 511-517.

Heptner, V. G. and Sludskii, A. A. 1992. "Mammals of the Soviet Union:
Carnivora (hyaenas and cats), Volume 2". Smithsonian Institution Libraries and National Science Foundation.

Holt, J.G., Kriey, N.R., Sneath, P.H.A. and Staley, J.T. 1994. Bergey's Manual of: Determinative Bacteriology. 9th edition. Lippincott Williams and Wilkins: Baltimore, USA.

Huijbers, P. M. C., Blaak, H., de Jong, M. C. M., Graat, E. A. M., VandenbrouckeGrauls, C. M. J. E. and de Roda Husman, A. M. 2015. Role of the environment in the transmission of antimicrobial resistance to humans: a review. Environmental Science and Technology, 49: 11993-12004.

Jobbins, S. E. and Alexander, K. A. 2015. From whence they came - antibioticresistant Escherichia coli in African wildlife. Journal of Wildlife Disease, 51: 811-820.

Jones, K.E., Patel, N.G., Levy, M.A., Storeygard, A., Balk, D., Gittleman, .L. and Daszak, P. 2008. Global trends in infectious diseases. Nature, 451:990993.

Kibret, M. and Abera, B. 2011. Antimicrobial susceptibility patterns of E. coli from clinical sources in northeast Ethiopia. African Health Sciences. 11: S40-S45.

Lloyd, D. H. 2007. Reservoirs of antimicrobial resistance in pet animals. Clinical Infectious Diseases, 45(Suppl. 2):S148-52.

Marshall, B. M., and Levy, S. B. 2011. Food animals and antimicrobials: Impacts on human health. Clinical Microbiology Reviews, 24(4): 718-733.

Mohammed, Z.A. and AL-Khyat, F. A. 2008. "Isolation and Identification of Escherichia coli O157:H7 from locally minced meat and imported minced and chicken meat". The Iraqi Veterinary Medical Journal, 32(1): 100-113.

Nagappa, K., Tamuly, S., Brajmadhuri, Saxena, M.K. and Singh, S.P. 2007. 
Isolation of Salmonella Typhimurium from poultry eggs and meat of Tarai region of Uttaranchal. Indian Journal of Biotechnology, 6: 407-409.

Paterson, D.L., Hujer K.M., Hujer, A.M., Yeiser, B., Bonomo, M.D., Rice, L.B. and Bonomo, R.A. 2003. Extendedspectrum beta-lactamases in Klebsiella pneumoniae bloodstream isolates from seven countries: dominance and widespread prevalence of SHV- and CTX-M-type beta-lactamases. Antimicrobial Agents and Chemotherapy, 47:3554-3560.

Pesapane, R., Ponder, M. and Alexander, K. 2013. Tracking pathogen transmission at the human-wildlife interface: banded mongoose and Escherichia coli. EcoHealth, 10: 115-128.

Peterson, D.L. and Bonomo, R.A. 2005. Extended spectrum beta-lactamases: A clinical update. Clinical Micro-biology Reviews, 18: 657-686.

Peterson, E. and Kaur, P. 2018. Antibiotic Resistance Mechanisms in Bacteria: Relationships Between Resistance Determinants of Antibiotic Producers, Environmental Bacteria, and Clinical Pathogens. Frontiers in Microbiology, 9:2928.

Pfeifer, Y., Cullik A. and Witte, W.2010. Resistance to cephalosporins and carbapenems in Gram-negative bacterial pathogens. International Journal of Medical Microbiology, 300:371-379.

Pitout, J. D. 2012. Extraintestinal pathogenic Escherichia coli: an update on antimicrobial resistance, laboratory diagnosis and treatment. Expert Review of Anti Infective Therapy, 10: 11651176

Rwego, I. B., Isabirye-Basuta, G., Gillespie, T. R. and Goldberg, T. L. 2008. Gastrointestinal bacterial transmission among humans, mountain gorillas, and livestock in Bwindi Impenetrable
National Park, Uganda. Conservation Biology, 22:1600-160710.

Sharma, S., Kaur, N., Malhotra, S., Madan, P., Ahmad, W. and Hans, C. 2016. "Serotyping and Antimicrobial Susceptibility Pattern of Escherichia coli Isolates from Urinary Tract Infections in Pediatric Population in a Tertiary Care Hospital". Journal of Pathogens, 2016:1-4.

Sood, S. 2016.Chloramphenicol - A Potent Armament Against Multi-Drug Resistant (MDR) Gram Negative Bacilli? Journal of Clinical and Diagnostic Research, 10(2): DC01DC03.

van den Bogaard, A. E. and Stobberingh E. E. 2000. Epidemiology of resistance to antibiotics. Links between animals and humans. International Journal of Antimicrobial Agents, 14: 327-33510.

Wasyl, D., Zając, M., Lalak, A., Skarżyńska, M., Samcik, I., Kwit, R., Jabłoński, A., Bocian, Ł., Woźniakowski, G., Hoszowski, A, and Szulowski, K.2018. Antimicrobial Resistance in Escherichia coli Isolated from Wild Animals in Poland. Microbial Drug Resistance. 24(6):807-815.

Weiss, D., Wallace, R.M., Rwego, I.B., Gillespie, T.R., Chapman, C.A., Singer, R.S. and Goldberg, T.L. 2018. Antibiotic-resistant Escherichia coli and class 1 integrons in humans, domestic animals, and wild primates in Rural Uganda. Applied and Environmental Microbiology, 84(21): e01632-18.

Wong, M.H., Chan, E.W. and Chen, S. 2015. Evolution and dissemination of oqxABlike efflux pumps, an emerging quinolone resistance determinant among members of Enterobacteriaceae. Antimicrobial Agents and Chemotherapy, 59:3290-3297. 


\section{How to cite this article:}

Chandrahas Sannat, Anil Patyal, Nidhi Rawat, Jasmeet Singh, Choodamani Chandrakar, Sanjay Shakya and Hirpurkar, S. D. 2020. Occurrence of Extended Spectrum Beta Lactamase Producing Escherichia coli in Hyena from Chhattisgarh, India. Int.J.Curr.Microbiol.App.Sci. 9(01): 1920-1927. doi: https://doi.org/10.20546/ijcmas.2020.901.215 